\title{
Perilaku Profesional Terhadap Pola Makan Sehat
}

\section{Albert Nathaniel, Galih Priya Sejati, Kevin Krisna Perdana, Riado Daniel Putra Lumbantobing, Sylvia Heryandini}

School of Business and Economics Universitas Prasetiya Mulya

JL. RA. Kartini (TB Simatupang), Cilandak Barat Jakarta Selatan, Jakarta 12430 Indonesia.

*. Corresponding Author: albertnathaniel91@gmail.com

\begin{tabular}{|c|c|}
\hline Abstract & ARTICLE INFO \\
\hline $\begin{array}{l}\text { A healthy lifestyle is the effective way to keep our body fit } \\
\text { and prevent our body from illness. Many diseases arise } \\
\text { primarily from irregular eating patterns and unhealthy } \\
\text { dietary intake. However, changes in lifestyles may lead } \\
\text { people to consume food without considering the nutritional } \\
\text { value. To address this issue, a survey was conducted on } \\
\text { professional workers to investigate their healthy diet using } \\
\text { explanatory research and processed through Microsoft Excel } \\
2013 \text { and SPSS } 25.0 \text { software, the test performed resulted in } \\
\text { a Pearson correlation of 0.918. Furthermore, statistically the } \\
\text { bivariate correlation test shows a strong linear correlation } \\
\text { between healthy diet levels and healthy food consumption } \\
\text { levels. }\end{array}$ & \multirow[t]{3}{*}{$\begin{array}{l}\text { Keyword: healthy diet, } \\
\text { healthy food, healthy fooc } \\
\text { consumption, professiona } \\
\text { workers, explanatory } \\
\text { research }\end{array}$} \\
\hline Abstrak & \\
\hline $\begin{array}{l}\text { Pola hidup sehat adalah cara terefektif untuk menjaga } \\
\text { kebugaran badan dan mencegah tubuh terserang dari } \\
\text { penyakit. Banyak penyakit yang muncul utamanya dari } \\
\text { pola makan yang tidak teratur dan konsumsi makanan } \\
\text { yang tidak sehat. Namun perubahan gaya hidup dapat } \\
\text { membuat nilai gizi dalam hal ini tidak menjadi } \\
\text { pertimbangan dalam pemilihan makanan. Atas hal } \\
\text { tersebut, dilakukan survei kepada pekerja professional } \\
\text { untuk investigasi pola makan mereka menggunakan } \\
\text { explanatory research yang diolah dengan } \\
\text { menggunakan program Microsoft Excel } 2013 \text { dan } \\
\text { software SPSS 25.0, menghasilkan pearson correlation } \\
\text { sebesar 0.918. Selanjutnya, secara statistik uji korelasi } \\
\text { bivariate yang dilakukan menunjukan korelasi linear } \\
\text { yang kuat antara tingkat pola makan sehat dan tingkat } \\
\text { konsumsi makanan sehat. }\end{array}$ & \\
\hline
\end{tabular}




\section{PENDAHULUAN}

Kesehatan adalah harta paling berharga dari kehidupan, seluruh aktivitas hanya bisa dilakukan ketika kondisi badan sehat. Menjalani pola makan sehat merupakan cara termudah untuk menjaga kebugaran badan dan mencegah tubuh terserang dari penyakit. Menjaga asupan makanan dan melakukan aktivitas fisik merupakan pondasi untuk memiliki tubuh yang sehat. Sayangnya, masih banyak orang yang tak tergerak meluangkan waktu untuk melakukannya. Khususnya bagi kalangan profesional di mana merupakan populasi terbesar di Indonesia yang berdasarkan data dari BPS mencapai 39.7\% di tahun 2017 di mana menghadapi banyak keterbatasan dalam ketersediaan waktu dan tempat.

Pola hidup sehat perlu diterapkan sejak awal agar memberikan dampak positif bagi tubuh. Banyak hal yang tanpa disadari justru jauh dari kebiasaan pola hidup sehat. Malas melakukan aktivitas fisik karena sudah dalam zona nyaman, mengonsumsi makanan cepat saji karena terbatasnya waktu, terlalu banyak bergadang karena pekerjaan atau bahkan hal yang tidak penting, adalah beberapa contoh pola hidup yang tidak sehat yang terkadang kita tidak sadari lakukan.

Tidak jarang sekarang ini, banyak penyakit yang datang menyerang di usia yang masih produktif seperti gangguan pencernaan, kolesterol, diabetes, ataupun obesitas. Semua disebabkan oleh pola hidup yang tidak sehat, utamanya dari pola makan yang tidak teratur. 
Disiplin terhadap pola makan adalah salah satu cara agar bisa mendapatkan hidup sehat yang jauh dari penyakit. Pola makan yang benar menurut Kementrian Kesehatan adalah gizi seimbang mengandung komponen-komponen yang kurang lebih sama, yaitu: cukup secara kuantitas, cukup secara kualitas, mengandung energi, protein, vitamin dan mineral yang diperlukan untuk menjaga kesehatan dan untuk melakukan aktifitas sehari-hari bagi semua kelompok umur dan kondisi fisik.

Kebiasaan makan dipengaruhi oleh faktor eksternal dan internal. Faktor eksternal meliputi ketersediaan pangan, status sosio-ekonomi dan kesadaran akan gizi. Faktor internal meliputi jenis kelamin, usia, citra tubuh, preferensi makanan dan tingkat kemandirian pola mengkonsumsi makanan yang terus berubah-ubah (Bonnie Worthington-Roberts and Williams, 2000).

Terdapat 5 faktor yang dapat mempengaruhi individu terhadap pemilihan makanan yaitu kognisi (sikap, preferensi, pengetahuan), keterampilan dan perilaku, pola hidup, biologis, dan demografi (Story et al., 2008).

Preferensi terhadap makanan didefinisikan sebagai derajat kesukaan atau ketidaksukaan terhadap makanan dan preferensi ini akan berpengaruh terhadap konsumsi pangan. Dalam memilih makanan tertentu yang disukai, terdapat beberapa faktor yang mempengaruhi yaitu antara lain enak, menyenangkan, tidak membosankan, berharga murah, mudah didapat dan diolah. Tampilan makanan merupakan hal yang berkontribusi paling besar terhadap preferensi konsumen. Sebagai dampaknya, nilai gizi dalam hal ini sering tidak dijadikan prioritas utama untuk pemilihan makanan. 
Perubahan pola hidup masyarakat khususnya dengan makanan yang dipilih, berkaitan juga pada perubahan budaya. Makanan yang berasal dari bahan alami seperti hasil pertanian yang meliputi beras, gandum, jagung menjadi lebih menarik lagi dengan pengolahan yang modern dari masa ke masa.

Selain pengolahan yang modern dan tuntutan mobilitas tinggi, makanan siap saji sering dijadikan pilihan utama yang diminati karena dianggap lebih cepat dan praktis. Dengan makanan cepat dan praktis, maka aktivitas tidak terganggu sehingga hal ini menjadi kebiasaan yang kurang baik.

Dengan kebiasaan yang kurang baik ini tercipta pergeseran pola hidup yang kurang sehat ini makin didukung oleh lingkungan sekitar dimana makanan siap saji disajikan dengan menawarkan tempat yang nyaman dan elit, dimana dekat dengan para pekerja professional dan lingkungan sosial mereka, sehingga mereka makin menggemari dan memiliki preferensi makanan siap saji.

Selain itu, perubahan pola hidup juga memiliki implikasi lainnya dimana tercipta persepsi baru pada masyarakat yaitu masyarakat yang konsumtif (consumer society). Perilaku masyarakat yang konsumtif ini tidak lepas dari pesatnya perkembangan teknologi sehingga berbagai iklan produk yang menawarkan berbagai jenis kebutuhan sangat mudah ditemui dan didapat, baik melalui media cetak atau elektronik.

Maka dari itu, terciptanya pola hidup sehat pada kalangan profesional memiliki kaitan dengan berbagai macam hal. Teknologi memudahkan pengguna dalam mendapatkan makanan yang kemudian menjadikan profesional lebih konsumtif yang cenderung 
memiliki efek negatif pada kemalasan masyarakat untuk bergerak akibat terbatasnya waktu dan tempat. Selain itu, kondisi ini diperparah dengan menjamurnya penyedia makanan cepat saji di sekitar lingkungan kerja di mana penyedia makanan cepat saji pasti berorientasi pada operasional yang praktis dan high margin tanpa memperhatikan tingkat kesehatan pada makanan yang mereka sediakan. Kombinasi beberapa penyebab tersebut berangsur-angsur membentuk suatu rutinitas dan perspektif khususnya dalam mengkonsumsi makanan sehari-hari di lingkungan kerja.

\section{TINJAUAN PUSTAKA}

Konsumsi makanan adalah kebutuhan primer yang mempunyai porsi besar yaitu ratarata sekitar 38\% dalam rata-rata pengeluaran bulanan di Indonesia, hal ini ditunjang dengan terdapat tren peningkatan dari 2 tahun untuk besar pengeluaran pangan terutama di makanan kemasan (Ho and Song, 2017).

Di tahun 2017, survei mengatakan bahwa kesadaran akan pola hidup sehat mengalami peningkatan dimana faktor kesehatan menjadi salah satu dari tiga besar faktor yang paling penting untuk preferensi makanan setelah rasa dan harga (Ho and Song, 2017). Konsumen di Indonesia menunjukan tren kemauan untuk membayar makanan lebih mahal untuk memperoleh makanan yang lebih sehat (Ho and Song, 2017).

Dalam dua dekade terakhir, terdapat perubahan yang signifikan di pemilihan dan konsumsi makanan. Konsumsi makanan di hampir sebagian besar negara berkembang sudah mencapai titik saturasi dalam konteks kuantitatif, kualitas makanan menjadi 
salah satu hal yang penting (Küster and Vila, 2017). Konsumen menjadi lebih mementingkan nutrisi dan kesehatan dari makanan, dimana konsumen saat ini sudah tersegmentasi dari pola hidup sehat yang mereka jalankan (Gil et al., 2000).

Pilihan pola hidup diasosiasikan dengan tingkat penyakit dan kematian. Riset menemukan bukti yang kuat bahwa menjalankan pola hidup sehat serta melakukan aktivitas fisik secara regular menurunkan resiko terkena penyakit (E.King et al., 2009).

\section{METODOLOGI PENELITIAN}

Melanjutkan riset yang sudah dilakukan sebelumnya serta menganalisis lebih jauh tentang pola hidup sehat dan tingkat konsumsi makanan sehat, penelitian dilakukan dengan mengerucutkan populasi yaitu fokus pada area Jabodetabek dan kalangan usia produktif yang bekerja (professional).

Metode penelitian yang digunakan adalah metode survei. Survei adalah metode riset yang berupa kuisioner sebagai alat pengumpul data dan bertujuan untuk mendapat informasi tentang sejumlah responden yang dianggap mewakili populasi tertentu (Kriyantono, 2008). Survei dilakukan melalui media Google Form.

Dalam metode survei ini dilakukan pengujian hipotesis atau penelitian penjelasan (explanatory research). Penelitian explanatory merupakan penelitian dengan menjelaskan hubungan antara variabel-variabel penelitian dan menguji hipotesis yang telah dirumuskan sebelumnya (Singarimbun and Effendi, 2008). Penelitian ini menggunakan pendekatan kuantitatif yang didukung oleh pendekatan kualitatif untuk 
memperoleh data primer. Kedua pendekatan tersebut juga dilengkapi dengan penelusuran literatur untuk memperoleh data sekunder.

Data yang digunakan dalam penelitian ini adalah data primer dan data sekunder. Data primer dikumpulkan dengan menggunakan pendekatan kuantitatif dan kualitatif sedangkan data sekunder dikumpulkan dengan menggunakan pendekatan studi literatur. Pendekatan kuantitatif digunakan untuk memperoleh data primer dengan menggunakan metode survei tehadap responden. Pendekatan kuantitatif dilakukan dengan menggunakan instrumen berupa kuesioner yang ditujukan kepada pekerja atau professional.

Pendekatan studi literatur dilakukan dengan penelusuran literatur untuk memperoleh data sekunder yang terkait dengan pola hidup sehat dan makanan sehat. Literatur tersebut dapat berasal dari dokumen-dokumen yang terkait dengan data-data mengenai topik dan tujuan penelitian, seperti buku teks, jurnal artikel, skripsi, tesis, dan karya ilmiah.

Data hasil kuesioner dari responden diolah dengan menggunakan program microsoft excel 2013 dan software SPSS 25.0 For Windows. Selain analisis data kuantitatif, dilakukan pula analisis data kualitatif sebagai pendukung. Data kualitatif akan diolah melalui tiga tahap analisis data kualitatif, yaitu reduksi data, penyajian data, dan penarikan kesimpulan. Penyimpulan hasil penelitian dilakukan dengan mengambil hasil analisis antar variabel yang konsisten. 
Hipotesis awal yang diidentifkasi adalah tidak adanya hubungan atau keterkaitan dari pola hidup sehat yang dijalankan oleh responden terhadap preferensi mereka dalam memilih makanan sehat.

\section{ANALISIS DATA}

Penelitian yang dilakukan melalui survei kepada 47 responden yang didapat dari sampling secara acak dari populasi kalangan professional yang berdomisili di area Jabodetabek.

Responden diminta untuk melakukan asesmen mandiri untuk menilai tingkat pola hidup sehat yang mereka jalani, hasil survei mengatakan $51 \%$ responden mengaku sudah mempunyai tingkat pola makan sehat yang tinggi dan $83 \%$ responden menyadari pola makan sehat sangat penting untuk diterapkan. Angka ini terbilang cukup tinggi dimana masyarakat sudah memilik respon positif serta kecenderungan untuk memiliki kualitas hidup yang lebih baik.

Jika dikaitkan dengan kesadaran hidup sehat serta tren pola makan sehat yang mulai meningkat, konsumsi makanan sehat juga dinilai sangat penting untuk dilakukan, hal ini didukung dari hasil survei yaitu $49 \%$ responden mengakui pentingnya mengkonsumsi makanan sehat.

Dari kedua hasil survei mengenai tingkat pola makan sehat dan tingkat konsumsi makanan sehat, terdapat indikasi hubungan keterkaiatan antar kedua variabel ini. Oleh karena itu, dilakukan analisis dengan menggunakan teknik korelasi bivariate 
untuk menguji apakah ada keterkaitan yang signifikan antara tingkat pola makan sehat dan tingkat konsumsi makanan sehat.

Data yang digunakan merupakan hasil survei dari masing-masing variabel, yaitu respon untuk pertanyaan asesmen mandiri tingkat pola makan sehat yang sudah diterapkan dan tingkat konsumsi makanan sehat.

Hipotesis awal $\left(\mathbf{H}_{0}\right) \quad$ : Tidak adanya hubungan yang signifikan antara tingkat pola makan sehat dan tingkat konsumsi makanan sehat.

Hipotesis alternatif $\left(\mathbf{H}_{1}\right)$ : Adanya hubungan yang signifikan antara tingkat pola makan sehat dan tingkat konsumsi makanan sehat.

Pengolahan uji keterkaitan atau korelasi dilakukan dengan menggunakan program SPSS dengan menggunakan selang kepercayaan (confidence level) 95\%, hasilnya dapat dilihat pada Tabel 1

Tabel 1 Hasil Analisis Korelasi Bivariate dengan SPSS

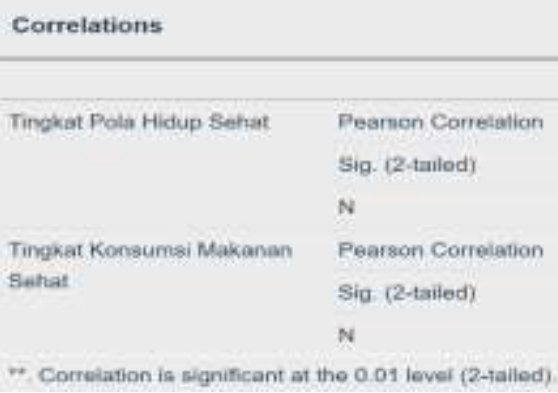

Dari tabel 1, hasil pearson correlation yang didapat adalah 0.918 dengan $p$-value $<0.01$

dimana dapat disimpulkan bahwa dengan selang kepercayaan 95\% (atau significant 
level 0.05) Hipotesis Awal $\left(\mathrm{H}_{0}\right)$ ditolak dan kedua variable yaitu tingkat pola makan sehat dan tingkat konsumsi makanan terdapat korelasi linear yang kuat.

Salah satu faktor yang mempengaruhi pola makan sehat adalah asupan makanan yang dikonsumsi, dikarenakan sumber energi dan juga faktor kesehatan sangat dipengaruhi oleh asupan makanan yang dikonsumsi.

Kalangan professional yang notabene-nya memiliki mobilitas yang tinggi mempunyai kebutuhan asupan makanan yang seimbang untuk memenuhi kebutuhan energi dan menjaga stamina untuk tetap bisa melakukan aktivitas. Mereka menyadari pentingnya pola makan sehat diterapkan untuk menunjang kebutuhan tersebut. Oleh karena itu terdapat korelasi linear (berbanding lurus) antara tingkat pola makan sehat dan tingkat konsumsi makanan sehat. Semakin tinggi tingkat pola makan sehat para professional, maka tingkat konsumsi makanan sehat juga semakin meningkat.

\section{KESIMPULAN}

Dari latar belakang serta hasil analisis yang sudah dibahas sebelumnya, dapat disimpulkan kesehatan menjadi salah satu concern utama terutama di kalangan professional. Untuk menunjang mobilitas tinggi, para professional memerlukan asupan energi yang cukup serta menjaga stamina untuk tetap dapat beraktivitas, sehingga para professional menyadari pentingnya untuk menjalankan pola makan sehat dengan salah satu caranya dengan mengkonsumsi makanan sehat.

Secara statistik uji korelasi bivariate yang dilakukan menunjukan korelasi linear yang kuat antara tingkat pola makan sehat dan tingkat konsumsi makanan sehat. Sehingga 
Vol.01, No. 2, 2018

tidak ada cukup bukti untuk menolak bahwa tidak ada hubungan antara tingkat pola makan sehat dan tingkat konsumsi makanan sehat. 


\section{DAFTAR PUSTAKA}

Bonnie Worthington-Roberts, Sue Williams. (2000). Nutrition Throughout the Life Cycle. Boston: McGraw-Hill.

Dana E.King, Arch G. Mainous III, Mark Camemolla, Charles J. Everett. (2009). Adherence to Healthy Lifestyle Habits in US Adults, 1988-2006. The American Journal of Medicine, 528-534.

Eugene Ho, Stanley Song. (2017). Embracing bricks and clicks in Indonesia. Deloitte Consumer Insight.

Inés Küster, Natalia Vila. (2017). Healthy lifestyle and eating perceptions: correlations with weight and low-fat and low-sugar food consumption in adolescence. Frontiers in Life Science.

J.M Gil, A Gracia, M Sánchez. (2000). Market segmentation and willingness to pay for organic products in Spain. The International Food and Agribusiness Management Review.

Kriyantono, R. (2008). Teknik Praktis Riset Komunikasi. Jakarta: Kencana Prenada Media Group.

Mary Story, Karen M. Kaphingst, Ramona Robinson-O'Brien, Karen Glanz. (2008). Creating Healthy Food and Eating Environments: Policy and Environmental Approaches. Annual Review of Public Health.

Masri Singarimbun, Sofian Effendi. (2008). Metode Penelitian Survei. Jakarta: LP3ES.

Sugiyono. (2008). Metode Penelitian Kuantitatif, Kualitatif dan R\&D. Bandung: Alfabeta. 


\section{LAMPIRAN}

Grafik Spending Trend on Beverages and Packages Food as part of Total Expenditure

Over 2015 - 2017

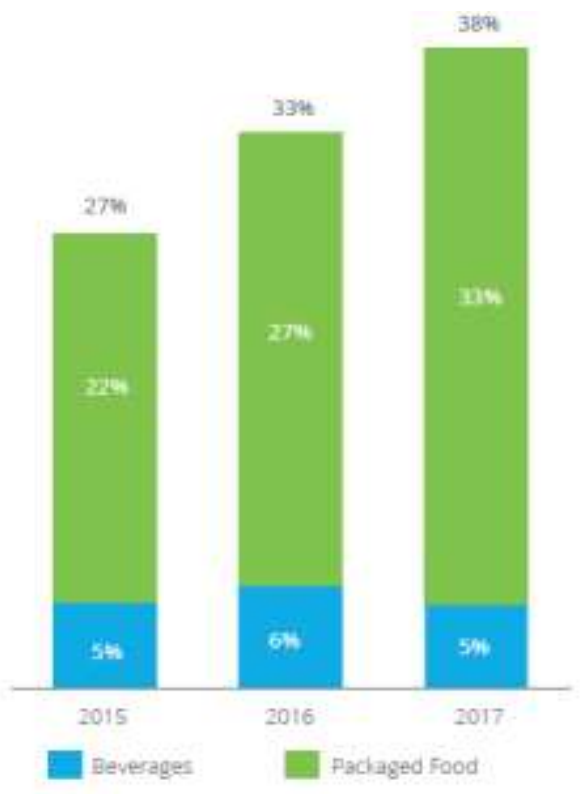

Source: Deloitte Consumer insights survey (2015, 2016, and 2017)

Source: (Eugene Ho, Stanley Song, 2017)

Grafik Tingkat Kepentingan Faktor yang Diperhatikan saat Konsumen Membeli

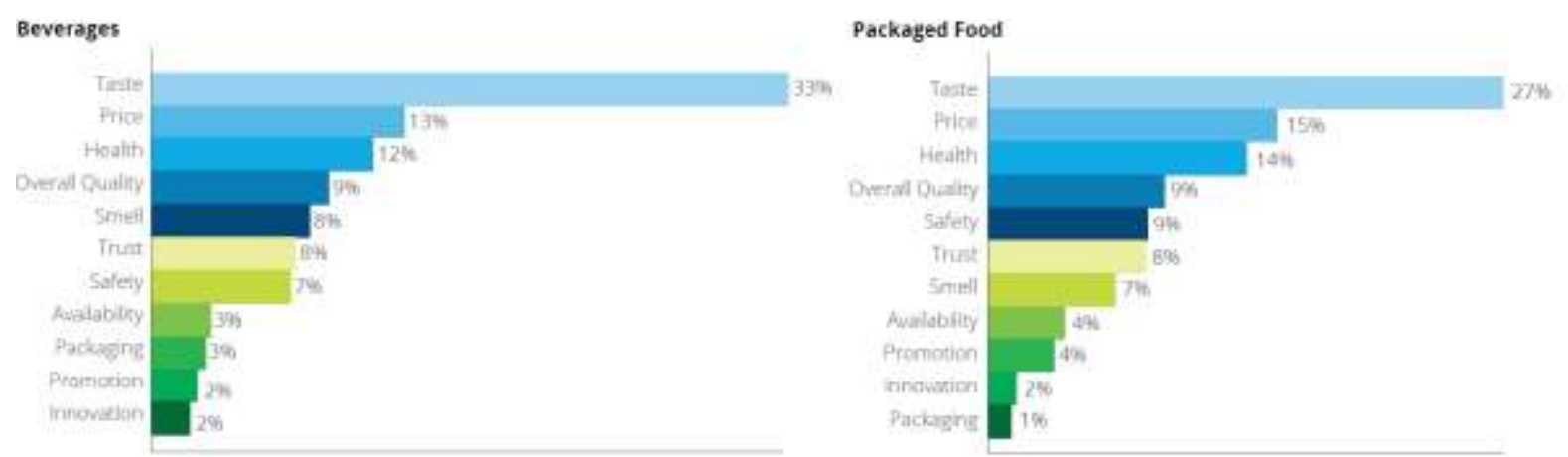

Source: (Eugene Ho, Stanley Song, 2017) 
Hasil Survey Tingkat Pola Hidup Sehat (Periode Survei: Juni 2016)

Skala 1 : Sangat Rendah

Skala 6 : Sangat Tinggi

Menurut Anda, seberapa tinggi tingkat pola makan sehat yang Anda jalani?

47 responses

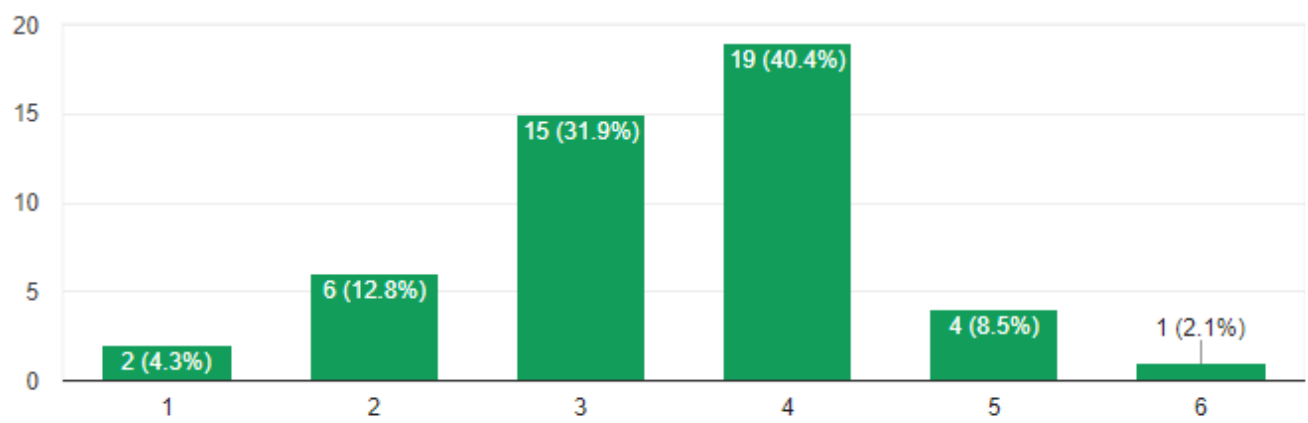

Hasil Survey Tingkat Konsumsi Makanan Sehat (Periode Survei: Juni 2016)

Skala 1 : Sangat Tidak Penting

Skala 6 : Sangat Penting

Seberapa penting menurut Anda mengkonsumsi makanan sehat?

47 responses

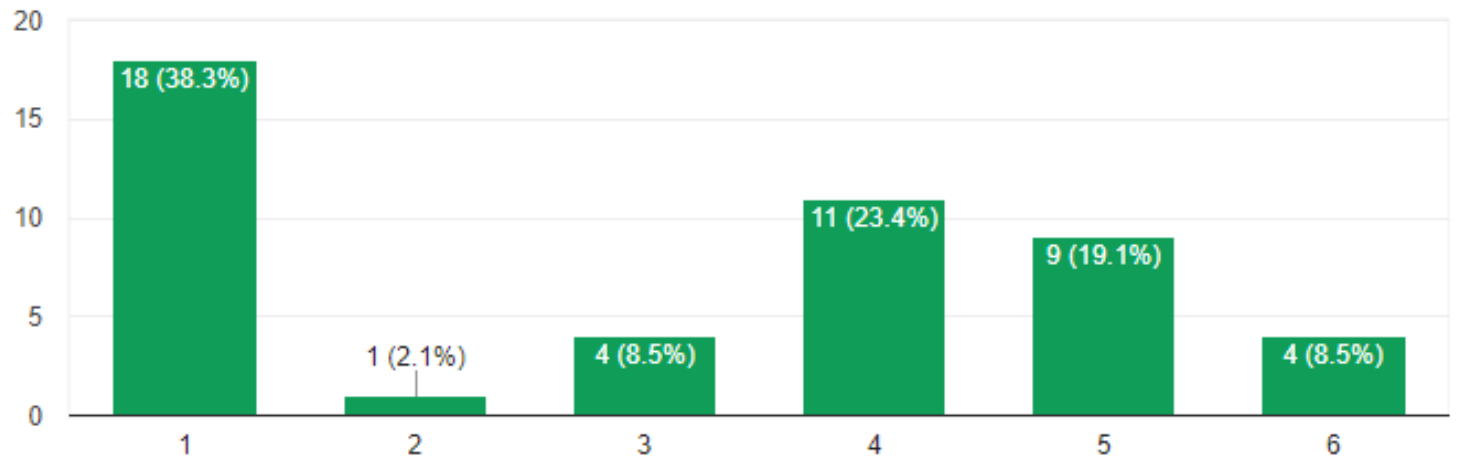


Vol.01, No. 2, 2018

Datasheeet Analisis Data Survei SPSS

\begin{tabular}{|c|l|}
\hline Nilai & Jenis Kelamin \\
\hline 1 & Pria \\
\hline 2 & Wanita \\
\hline
\end{tabular}

\begin{tabular}{|c|l|}
\hline Nilai & Umur \\
\hline 22 & Golongan 22-40 tahun \\
\hline 41 & Golongan di atas 40 tahun \\
\hline
\end{tabular}

\begin{tabular}{|c|l|}
\hline Nilai & Tingkat Pola Hidup Sehat \\
\hline 0 & Skala $1-3$ \\
\hline 1 & Skala $4-6$ \\
\hline
\end{tabular}

\begin{tabular}{|c|l|}
\hline Nilai & Tingkat Konsumsi Makanan Sehat \\
\hline 0 & Skala $1-3$ \\
\hline 1 & Skala $4-6$ \\
\hline
\end{tabular}

\begin{tabular}{|c|c|c|c|c|c|}
\hline \multicolumn{2}{|c|}{ Pertanyaan Survei } & \multicolumn{2}{|c|}{$\begin{array}{l}\text { Menurut Anda, seberapa tinggi tingkat pola } \\
\text { hidup sehat yang Anda jalani? }\end{array}$} & \multicolumn{2}{|c|}{$\begin{array}{l}\text { Seberapa penting menurut Anda } \\
\text { mengkonsumsi makanan sehat? }\end{array}$} \\
\hline $\begin{array}{c}\text { Jenis } \\
\text { Kelamin }\end{array}$ & Umur & Data Aktual Survei & Tingkat Pola Hidup Sehat & Data Aktual Survei & $\begin{array}{c}\text { Tingkat Konsumsi } \\
\text { Makanan Sehat }\end{array}$ \\
\hline 1 & 22 & 3 & 0 & 1 & 1 \\
\hline 2 & 22 & 5 & 1 & 4 & 1 \\
\hline 2 & 22 & 4 & 1 & 5 & 1 \\
\hline 1 & 22 & 3 & 0 & 1 & 1 \\
\hline 1 & 22 & 1 & 0 & 3 & 0 \\
\hline 1 & 22 & 2 & 0 & 3 & 0 \\
\hline 1 & 22 & 5 & 1 & 4 & 1 \\
\hline 2 & 22 & 4 & 1 & 4 & 0 \\
\hline 2 & 22 & 4 & 1 & 6 & 0 \\
\hline 1 & 22 & 5 & 1 & 4 & 1 \\
\hline 2 & 22 & 3 & 0 & 5 & 0 \\
\hline 2 & 22 & 6 & 1 & 4 & 1 \\
\hline 2 & 22 & 3 & 0 & 1 & 1 \\
\hline 2 & 41 & 4 & 1 & 5 & 1 \\
\hline 2 & 22 & 4 & 1 & 5 & 1 \\
\hline 1 & 22 & 4 & 1 & 4 & 0 \\
\hline 1 & 22 & 5 & 1 & 5 & 0 \\
\hline 1 & 22 & 4 & 1 & 5 & 1 \\
\hline 1 & 22 & 2 & 0 & 3 & 1 \\
\hline 1 & 22 & 3 & 0 & 1 & 1 \\
\hline 1 & 22 & 3 & 0 & 1 & 1 \\
\hline 1 & 22 & 3 & 0 & 1 & 1 \\
\hline 1 & 22 & 4 & 1 & 4 & 1 \\
\hline 1 & 22 & 4 & 1 & 4 & 1 \\
\hline 1 & 22 & 3 & 0 & 1 & 1 \\
\hline 2 & 41 & 3 & 0 & 1 & 1 \\
\hline 2 & 41 & 4 & 1 & 6 & 0 \\
\hline 2 & 41 & 4 & 1 & 6 & 0 \\
\hline 2 & 22 & 3 & 0 & 1 & 1 \\
\hline 2 & 41 & 3 & 0 & 4 & 0 \\
\hline 1 & 22 & 2 & 0 & 1 & 1 \\
\hline 2 & 22 & 2 & 0 & 1 & 1 \\
\hline 1 & 22 & 2 & 0 & 1 & 1 \\
\hline 2 & 41 & 4 & 1 & 5 & 1 \\
\hline 1 & 22 & 4 & 1 & 4 & 1 \\
\hline 2 & 22 & 4 & 1 & 5 & 0 \\
\hline 1 & 41 & 2 & 0 & 1 & 1 \\
\hline 1 & 22 & 4 & 1 & 4 & 1 \\
\hline 2 & 22 & 3 & 0 & 1 & 1 \\
\hline 1 & 22 & 3 & 0 & 1 & 1 \\
\hline 1 & 22 & 3 & 0 & 1 & 1 \\
\hline 2 & 22 & 3 & 0 & 3 & 1 \\
\hline 1 & 22 & 4 & 1 & 5 & 1 \\
\hline 1 & 22 & 4 & 1 & 6 & 1 \\
\hline 1 & 22 & 4 & 1 & 2 & 1 \\
\hline 2 & 22 & 1 & 0 & 1 & 1 \\
\hline 1 & 22 & 4 & 1 & 1 & 1 \\
\hline
\end{tabular}

